\title{
«Desde el sagrado púlpito y en exhortaciones privadas»: la circulación de información durante la guerra de Independencia peruana
}

\section{«From the sacred pulpit and in private exhortations»: information circulation during Peru's war of Independence}

MARÍA CLAUDIA HUERTA VERA

Universidad de California, Davis

mchuerta@ucdavis.edu

\section{RESUMEN}

Este ensayo analiza la manera en que la información circulaba y se difundia durante la guerra de Independencia peruana, especificamente entre 1820 y 1824. Para estudiar el verdadero alcance del material impreso que tanto el bando realista como el patriota se esforzaron en publicar y difundir, es indispensable analizar tanto las formas en que los papeles impresos pasaban de una mano a otra como la manera en que la información contenida en ellos se difundía de forma oral entre la población. El carácter propagandístico de la imprenta durante la guerra es innegable y esperable. Lo que es más interesante es que además de las autoridades militares de cada bando interesadas en que la palabra impresa llegara a todo el territorio peruano, se encontraban los sacerdotes como agentes esenciales para la difusión de esta propaganda. Los miembros del clero tenian una plataforma fija dispuesta a recibir sus mensajes y, además, contaban con la autoridad espiritual que su cargo les otorgaba. Así, su voz fue fundamental para difundir la palabra impresa en una sociedad en donde todavía primaba la oralidad.

Palabras clave: Independencia del Perú, prensa periódica, información, circuitos de comunicación, clero 


\section{ABSTRACT}

This essay examines the mechanisms of information dissemination during Peru's war of independence, mainly in 1820-1824. Assessing the outreach of printed propaganda produced by both royalists and patriots involves establishing how it was passed around or spread by word of mouth among the population. While propaganda was mainly promoted by the military authorities on each side, the Church's network and spiritual influence played a key role in its dissemination in a society where oral communication was still the main way to transmit information.

Keywords: Peru's war of independence, printed press, information, communication circuit, clergy

U no de los personajes inmortalizados por Ricardo Palma (18331919) en sus Tradiciones peruanas fue el sacerdote franciscano Bruno Terreros del curato de Chupaca. Fiel a Dios y a la Corona española, en la plática dominical, se dedicó a criticar las ideas independentistas y revolucionarias. ${ }^{1}$ Todo cambió el día que una tropa realista llegó a su jurisdicción y lo amenazó con violencia. Para defenderse, el franciscano amotinó a la población y se enfrentó a los soldados con ella. Así, «colgó los hábitos, se plantó al cinto sable y pistolas, y, trabuco en mano, se puso a la cabeza de doscientos montoneros». ${ }^{2}$ A partir de entonces, el coronel fray Bruno, además de dirigirse a sus feligreses desde el púlpito, contribuyó a la transmisión de las ideas independentistas a través de la escritura de efusivas proclamas que lograron inflamar el ánimo de los montoneros patriotas que lo seguían. Cuenta Palma que él predicaba "con el Evangelio en una mano y el trabuco en la otra, como lo hicieron en Francia los sacerdotes de la Vendée». ${ }^{3}$ De este modo, fray Bruno logró que aquellos guerrilleros lucharan por lograr la Independencia como si se tratase de conquistar su propia salvación. ${ }^{4}$

1 Palma 1983, VI: 52.

2 Ib.

3 Ib.: 53 .

$4 \mathrm{Ib}$. 
Un ejemplo como este, incluso envuelto por el halo de ficción que acompaña a cualquier obra literaria, ilustra muy bien el escenario que se vivía en el Perú durante la guerra de Independencia. Esta no solo se llevó a cabo en los campos de batalla, sino que también dio origen a una importante "guerra de palabras" ${ }^{5}$ en la que personajes como el fraile y militar Bruno Terreros cobraron vital importancia. El objetivo de este ensayo es justamente analizar la manera en que la información circulaba y se difundía durante la guerra de Independencia peruana. Esta investigación se inserta en distintas corrientes historiográficas. Además de enmarcarse en el amplio panorama de la historia de las independencias hispanoamericanas, también se nutre de la historia de la cultura política. Pero, sobre todo, y de manera más precisa, se inscribe en la llamada historia del libro o la lectura, un campo de investigación que tiene como principal objetivo entender la forma en que las ideas se han transmitido por medio de la palabra impresa y cuál ha sido el efecto de su difusión. ${ }^{6}$ Es desde este campo que se usa como marco teórico el circuito de la comunicación de Robert Darnton, como se verá más adelante. Además, fueron tres los trabajos clave que perfilaron, cuestionaron e inspiraron esta investigación. Primero, se encuentra el ensayo de Pedro Guibovich Pérez, «Letras de molde y revolución: la imprenta durante la guerra de la independencia», ${ }^{7}$ pues aborda por primera vez de manera central y directa una pregunta fundamental: de qué manera se transformó la producción impresa como efecto de la guerra de independencia en el Perú. Segundo, se encuentra el ensayo de Rebecca Earle, «Information and Disinformation in Late Colonial New Granada», ${ }^{8}$ pues, aunque no estudia el caso peruano, sí describe y analiza la forma en que circulaban las noticias en una sociedad con características muy parecidas a la nuestra. Y tercero, se encuentra el libro de Roberto di Stefano, El púlpito y la plaza: clero, sociedad y politica de la monarquía católica a la república

5 Mc Evoy 1996: 98.

6 Darnton 2010a: 117.

7 Guibovich 2012.

8 Earle 1997. 
rosista, ${ }^{9}$ el cual, aunque nuevamente no estudia el caso peruano, sí fue fundamental para comprender el importante rol del clero en la difusión de mensajes e información.

A partir de lo trabajado por estos y otros autores y de las fuentes primarias disponibles, este ensayo analiza la manera en que la información circulaba y se difundía durante la guerra de Independencia peruana, específicamente entre 1820 y 1824 . En las siguientes páginas, se explica cómo además de las autoridades militares de cada bando interesadas en que la palabra impresa llegara a todo el territorio peruano, se encontraban los sacerdotes como agentes esenciales para la difusión de esta propaganda de manera oral. Para ello, en primer lugar, se evalúa de manera general el efecto de la guerra sobre la cultura del impreso: se muestra cómo el difícil escenario político y militar de la época aceleró el desarrollo de la industria tipográfica en el Perú en relación con las prácticas de lectura. En segundo lugar, se aborda la forma en que la cultura impresa se articulaba con la cultura manuscrita y la cultura oral. Finalmente, se estudian de manera más precisa algunas de las prácticas y dinámicas que permitían la circulación de información: la lectura y la discusión de papeles públicos; el rol que jugó la Iglesia y el clero como institución; la transmisión e intercepción de comunicaciones en el territorio nacional; y el rol que tuvieron los sacerdotes patriotas en la lucha por la Independencia peruana.

\section{LA CULTURA DEL IMPRESO Y EL CIRCUITO DE LA COMUNICACIÓN}

Como se mencionó líneas arriba, en esta primera parte se mostrará cómo la guerra de Independencia aceleró el desarrollo de la industria tipográfica en el Perú y transformó algunas de las prácticas de lectura. La prensa periódica fue utilizada como medio de propaganda, tanto por el bando realista como por el patriota, pero, además de esta, un gran número de proclamas, edictos, bandos, canciones, exhortaciones y reglamentos circuló entre la población. Una de las consecuencias directas de la guerra fue justamente la transformación de la llamada cultura del impreso,

9 Di Stefano 2004. 
entendida esta como el espacio de articulación entre los procesos de producción, circulación y recepción del material impreso y la interacción entre los agentes que forman parte de este circuito. ${ }^{10}$ Este último punto es fundamental, pues exige no solo el estudio de los procesos técnicos y económicos necesarios para la producción tipográfica, sino también el análisis de las prácticas sociales surgidas en torno a la imprenta y la relación entre la población y los textos impresos.

Pensar en la cultura del impreso y, específicamente, en los procesos de producción, circulación y recepción es pensar en un circuito. Estos procesos están interconectados y se retroalimentan constantemente. Por ello, se escogió el circuito de la comunicación de Robert Darnton como marco teórico. ${ }^{11}$ Si bien el esquema de Darnton fue pensado especialmente para el caso de los libros en el siglo XVIII, esto no quiere decir que no pueda aplicarse también a otros periodos de la historia del libro - como la guerra de Independencia peruana — o incluso a otros medios impresos — como publicaciones periódicas, proclamas o panfletos-. Se pueden hacer modificaciones al circuito, pero el principio de este sigue siendo el mismo: «representar el proceso de comunicación de forma tal que haga justicia a su naturaleza sistemática y a la intercomunicación de sus partes». ${ }^{12}$ Además, dado que las cinco etapas que presenta este modelo guardan una estrecha relación con los tres procesos principales de la cultura del impreso — producción, circulación y recepción-, es posible establecer un paralelo y ubicar a cada uno de los agentes identificados por Darnton en un proceso específico.

${ }^{10}$ Esta definición se ha elaborado a partir del trabajo de José Ragas (2009: 45) y, en especial, del artículo de Harold Love (2003: 45-64). Cada autor ofrece una manera de entender la cultura del impreso que varían en aspectos específicos, pero coinciden en resaltar las tres partes del proceso: producción, circulación y recepción.

${ }^{11}$ Darnton 2010a: 122 y 2008: 275.

${ }^{12}$ Darnton 2008: 276. 


\section{ProduCCIÓN, CIRCULACIÓN Y RECEPCIÓN}

EN EL CIRCUITO DE LA COMUNiCACión DE Robert DARNTON

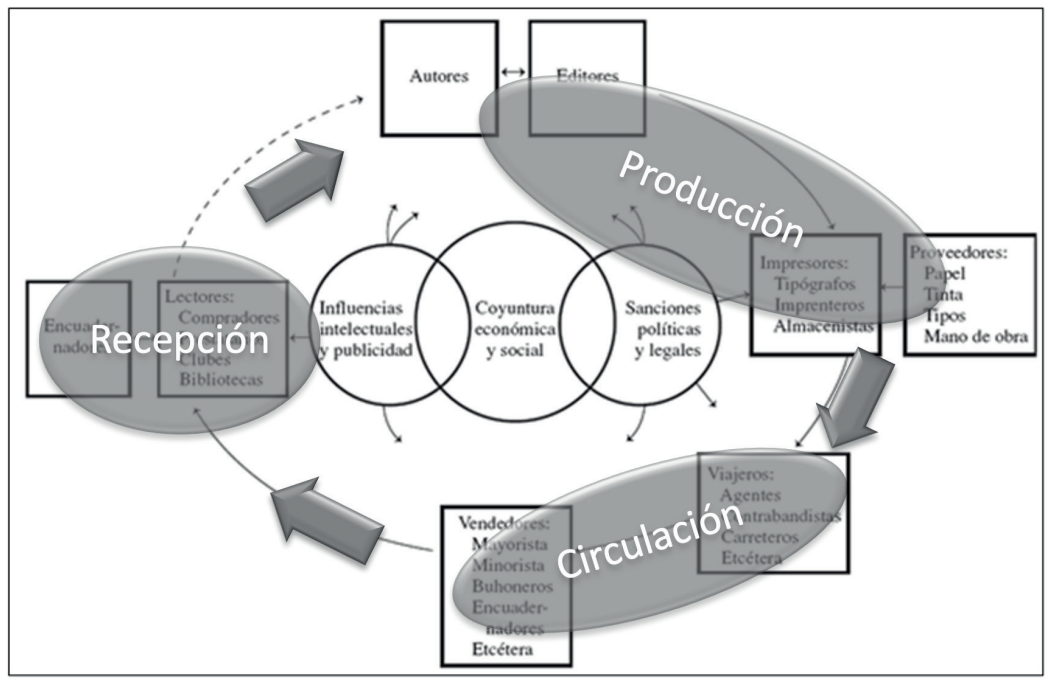

Fuentes: Darnton 2010a: 122 y 2008: 275

$\mathrm{Al}$ inicio del esquema, trabajando conjuntamente y al mismo nivel, están los autores y editores, seguidos por los impresores y proveedores, estos últimos a cargo de los aspectos más técnicos del proceso de producción. En el Perú colonial, era bastante común que el impresor hiciera también las veces de editor e incluso de autor. El mundo editorial era muy pequeño. Dado el reducido desarrollo de esta industria tipográfica, los impresores siempre fueron pocos en número. Por mucho tiempo, el taller de Antonio Ricardo — quien trajo la primera imprenta a América del Sur a finales del siglo XVI — fue el único que funcionó en el virreinato peruano, primero bajo su administración y después bajo la de Francisco del Canto. ${ }^{13}$ Aunque durante la segunda mitad del siglo XVIII se puede

${ }^{13}$ El impresor turinés Antonio Ricardo llegó con una imprenta de caracteres móviles a la ciudad de Los Reyes en 1581, pero no fue sino hasta 1584, cuando se levantó la prohibición de la Corona de establecer imprentas en el virreinato peruano, que su uso se hizo efectivo (Vargas Ugarte 1953: xv). 
apreciar un importante desarrollo en esta industria, ${ }^{14}$ hasta los primeros años del siglo XIX no solían ser más de dos o tres los talleres que podían funcionar en Lima al mismo tiempo. Estos, además, salvo una debatida excepción a inicios del siglo XVII, ${ }^{15}$ nunca funcionaron en otra ciudad que no fuera la capital. ${ }^{16}$

En cuanto al proceso técnico de producción en sí, es necesario mencionar que este no había cambiado mucho desde la invención de la imprenta. Por ello, la calidad de los textos que se imprimían durante las primeras décadas del siglo XIX siguió manteniendo los estándares de épocas anteriores: no faltaron impresiones poco legibles o de mala calidad. Los impresores tenían que lidiar con obstáculos materiales como la escasez y el alto costo de insumos como la tinta y el papel. La maquinaria y las herramientas tampoco eran fáciles de conseguir. Con frecuencia, se usaban caracteres tipográficos gastados de segunda mano y, peor aún, dado que era común que las prensas se pasaran de un impresor a otro, se seguían usando los mismos materiales por muchos años. ${ }^{17} \mathrm{El}$ resultado de esta forma de trabajo eran impresos de una calidad que estaba por debajo de los estándares españoles e incluso de los novohispanos.

El estallido de la guerra de Independencia se encuentra al centro del circuito de la comunicación, pues afectó la coyuntura económica y social a la que se refiere Darnton en su esquema. El principal cambio en cuanto al funcionamiento de los talleres en el virreinato peruano fue que, a partir de 1820, el Perú contó no solo con imprentas estables, sino que aparecieron las imprentas volantes. Estas, a diferencia de las primeras, podían transportarse, por lo que, aunque eran más precarias que las estables, les permitían a los ejércitos llevarlas consigo en sus campañas. Otro cambio

${ }^{14}$ Gracias a las reformas implementadas por el gobierno Borbón para lograr una administración más eficiente y ordenada, muchas oficinas civiles y eclesiásticas emplearon a impresores y encuadernadores para agilizar la labor tradicionalmente encargada a los copistas (Guibovich Pérez 2014: 167).

${ }^{15}$ Se trata de la posibilidad de que, por un corto periodo de tiempo en 1612, la imprenta de Francisco del Canto haya funcionado en Juli, en el actual departamento de Puno.

${ }^{16}$ Para un repaso general de la historia de la imprenta y los impresores desde el siglo XVI, véase Vargas Ugarte 1953 y Medina 1966, I: xix-xcviii.

${ }^{17}$ Guibovich Pérez 2019. 
fundamental se produjo sobre las sanciones políticas y legales que regían la imprenta. A pesar de que el 10 de noviembre de 1810 se promulgó un decreto de libertad de imprenta - como resultado de la crisis de la monarquía española y la formación de las Cortes de Cádiz_-, recién en 1820 se consolidó la demanda por una imprenta libre, cuando se sancionó el Decreto Regulador de la Libertad de Imprenta de forma definitiva. ${ }^{18}$ De esta forma, la censura previa, que desde 1502 ordenaba que ningún libro fuese impreso, importado o expuesto para la venta sin el examen y la licencia previos del Consejo Real de Castilla, ${ }^{19}$ dejó de ejercerse sobre la imprenta en el territorio peruano.

La necesidad de contar con una imprenta en este contexto bélico era grande, por lo que no debe sorprender que su número empezara a aumentar. La Expedición Libertadora que desembarcó en las playas de Pisco bajo el mando de José de San Martín trajo una imprenta volante con ella. No solo eso. Sin contar la imprenta del Ejército Libertador, son por lo menos seis las imprentas que en 1820 funcionaron en Lima al mismo tiempo. Y luego, entre 1820 y 1824, este número aumentó aún más, pues llegaron a funcionar hasta once imprentas en la ciudad. ${ }^{20}$ Este incremento es verdaderamente significativo si se considera que, durante

${ }^{18}$ De hecho, el virrey Joaquín de la Pezuela recibió el decreto de Fernando VII que ordenaba el restablecimiento de la Constitución de Cádiz el 4 de septiembre de 1820, cuando San Martín estaba por desembarcar en las playas peruanas (Peralta 2010: 287). El decreto en sí se sancionó el mes siguiente, el 22 de octubre de 1820, después de que las Cortes reunidas en Madrid dedicaran su primera legislatura ordinaria a debatir las reformas que se debían introducir al decreto de 1810. Si bien se mantuvieron los principios fundamentales de este, se fijaron con mayor precisión las facultades de la Junta Conservadora de la Libertad de Imprenta y las penas a que se hacían acreedores los que abusaban de tal derecho. En Lima, la difusión del nuevo reglamento se hizo en $E l$ Triunfo de la Nación el 24 de abril y el 8 de mayo de 1821, es decir, seis meses después de aprobarse en las Cortes (Peralta Ruiz 2011: 732). El Protectorado de San Martín refrendó el Decreto Regulador de la Libertad de Imprenta el 13 de octubre de 1821.

${ }^{19}$ Guibovich Pérez 2014: 164.

${ }^{20}$ Se trata de las imprentas de los Niños Huérfanos, de Ruíz, de Río, de José Antonio López, de José Masías, de la calle de Bravo, de la calle de San Jacinto, de la calle de Palacio, la Imprenta Peruana, la Imprenta de Gobierno y la de José María Concha. Las diez primeras se han podido identificar en Huerta Vera 2017: 79-81; la de José María Concha es mencionada por Guibovich Pérez (2012: 135) y Vargas Ugarte (1957b: 329). 
todo el periodo colonial, no era usual que funcionaran más de tres talleres a la vez; incluso durante el pequeño periodo de la crisis de la monarquía española en que se liberó la imprenta, el número aumentó solo a cuatro. ${ }^{21}$

Lo más llamativo, sin embargo, no es lo que ocurría en Lima, sino lo que estaba pasando en el resto del virreinato. El enfrentamiento entre los bandos realista y patriota llevó a que varias ciudades distintas a la capital empezaran a desarrollar, por necesidad, una industria tipográfica local. Esto, una vez más, empezó en 1820 con la llegada de San Martín. La imprenta volante que el general argentino trajo consigo comenzó a funcionar inmediatamente, pues el mismo 8 de septiembre de 1820, el "primer día de la libertad del Perú», San Martín dirigió una proclama al ejército y a los habitantes del país. Y, cuando el ejército se trasladó al norte, su imprenta volante les permitió circular una cantidad considerable de hojas revolucionarias desde Supe, Huacho, Ancón y Huaura. En estas localidades, se publicó el primer periódico independiente, El Boletín del Ejército Unido Libertador del Perú, que llegó a tener hasta once números entre octubre de 1820 y marzo de $1821 .{ }^{22}$ El 10 de abril de ese mismo año, en Huaura, se empezó a publicar El Pacificador del Perú en la imprenta de José Antonio López, «en atención a la escasez de la del ejército y sus muchas ocupaciones», como especifica su primer número. Su último número se publicó el 1 de septiembre, en Lima, cuando la Independencia ya se había proclamado. ${ }^{23}$

La imprenta y los impresores que la operaban eran elementos importantes tanto para el bando patriota como para el realista; al punto de que la prensa, y con ella el periódico que estuviese publicando, se trasladaban a donde el ejército lo hiciera, incluso a lugares que nunca habían contado con una prensa de caracteres móviles. De esta manera, el virrey José de La Serna, al abandonar Lima en los primeros días de julio de 1821, también se llevó una imprenta volante consigo para difundir en el centro del país las circulares y proclamas realistas. La primera de estas apareció en Jauja, el 11 de septiembre de 1821, dirigida a los habitantes

${ }^{21}$ Las cifras ofrecidas en este párrafo se encuentran en Huerta Vera (2017: 17-37 y 79-81).

${ }^{22}$ Vargas Ugarte 1953: xlvi-xlvii.

${ }^{23}$ Guibovich Pérez 2012: 138. 
del Perú; y otras dos proclamas se publicaron en Huancayo, el 15 de noviembre, y en Huamanga, el 18 del mismo mes. ${ }^{24}$

De esta forma, las imprentas volantes o portátiles pudieron llegar a muchas localidades del país y, así, la capital dejó de ser la única ciudad con talleres tipográficos. Trujillo, por ejemplo, se convirtió en un activo centro editorial patriota; primero con la introducción de una imprenta volante en $1820 \mathrm{y}$, posteriormente, con la adquisición por la Municipalidad de la Imprenta de Manuel del Río, en 1823. ${ }^{25}$ Solo un año después, en 1824, la ciudad contaría ya con cuatro imprentas: la de la Municipalidad, la del Estado, la de Trujillo y la de la Ciudad. ${ }^{26}$ La comparación de este escenario con la situación editorial vivida tan solo unos pocos años antes es verdaderamente impresionante y demuestra el gran impacto que tuvo la guerra en la actividad editorial. Y todo esto solo en el campo de la producción.

En el campo de la circulación, también se produjeron cambios importantes. Los agentes protagonistas de este proceso, según el circuito de la comunicación de Darnton, eran los transportistas y los vendedores. Estos agentes eran esenciales para la circulación de libros en Europa durante el siglo XVIII, pero para la circulación de textos impresos de distintos formatos en el virreinato peruano a inicios del siglo XIX, otros eran los personajes que ocupaban su lugar. De ellos y de las dinámicas que permitían que no solo los impresos sino también la información que ellos contenían circulara en el país, se ocupará la siguiente sección.

Finalmente, en el campo de la recepción, los protagonistas son los lectores (y, en el esquema de Darnton para los libros del siglo XVIII, también los encuadernadores). Estudiar la recepción, la forma en que los lectores de la época leían e interpretaban los textos impresos, es tan

\footnotetext{
${ }^{24}$ Vargas Ugarte 1953: xlvii.

${ }^{25}$ En 1822, Manuel del Río, hijo del famoso editor e impresor Guillermo del Río, «se trasladó a Trujillo con el objeto de venderle una imprenta a la Municipalidad de la mencionada ciudad, adquisición que se hizo efectiva el 4 de febrero de 1823 . Esta sería la primera imprenta en la historia de Trujillo, hecho que confirma una tendencia común en toda la América hispana durante las guerras de independencia de inicios del siglo XIX, a saber: dicho conflicto militar hizo posible el establecimiento de la imprenta en ciudades y pueblos que hasta entonces habían carecido de ella» (Niada 2011: 27-28).

${ }^{26}$ Medina 1904.
} 
interesante como complicado. En última instancia, permitiría responder la pregunta sobre si la imprenta determinó o no el resultado de la guerra de Independencia, al influir los textos impresos en la opinión pública y en el actuar individual o colectivo de la sociedad. Aunque este tema específico es uno que se debe seguir estudiando, sí es posible afirmar que la imprenta tuvo una influencia importante en el conflicto (a la vez que el conflicto en sí mismo, como se ha visto, aceleró el desarrollo de la imprenta). ${ }^{27}$

Por esto mismo, los lectores pueden completar el circuito de la comunicación a través de la retroalimentación que reciben de ellos los autores; es decir, la respuesta de estos últimos es capaz de influir en la producción de nuevos contenidos. En ese sentido, lo que un esquema como el de Darnton aplicado al contexto peruano permite explicar es que, debido al difícil escenario político y militar de la época que aceleró el desarrollo de la industria tipográfica, la cultura del impreso, tal y como se definió líneas arriba, logró llegar a más personas de manera cada vez más directa —es decir, los espacios de articulación entre cada proceso se expandieron-y las interacciones entre los personajes que forman parte del circuito —incluida la interacción entre el lector y el autor - fueron cada vez más viables, rápidas y eficientes: había más respuesta porque se estaban transformando las propias prácticas de lectura. De estos tres procesos, nos centraremos en el más dinámico: la circulación.

\section{ENTRE LO ESCRITO Y LO ORAL}

Como consecuencia de los cambios en el proceso de producción, los textos impresos podían llegar cada vez a más personas, aunque fuesen todavía pocas las que pudiesen leerlos de primera mano. Por ello, además de la transmisión o distribución de los papeles impresos como objeto material, cualquiera sea su formato, es necesario considerar la importancia de las vías orales. ${ }^{28}$ Esto implica comprender la forma en que la cultura

\footnotetext{
${ }^{27}$ Huerta Vera 2017: 55-74; y 2019.

${ }^{28}$ Por ejemplo, en un trabajo que analiza el impacto de la Revolución Francesa en el Perú, Claudia Rosas presenta un capítulo dedicado a la difusión y circulación de noticias desde la última década del siglo XVIII hasta 1808. En él, se hace énfasis en la importancia de las vías tanto escritas como orales para que la comunicación sea posible, en tanto cada
} 
impresa se articulaba con la cultura manuscrita y la cultura oral. Darnton, por ejemplo, ilustra la importante conexión entre lo escrito y lo oral en su ensayo sobre los circuitos de comunicación en la Francia del siglo XVIII. Para él, «el habla y la escritura, la escucha y la lectura, marchaban en conjunto y se amplificaban mutuamente de manera que difundían la información a todas partes». ${ }^{29}$ Muy difícilmente la información podía restringirse al material impreso. Normalmente, esta pasaba a una forma oral para poder seguirse transmitiendo. Esto permitía que llegara a una mayor cantidad de gente, puesto que el público lector no se restringía solo a las personas letradas que podían tener acceso directo al material impreso. Para Darnton, la opinión pública «emergía siempre del mutuo refuerzo entre dos fenómenos, la imprenta y la conversación»; «la palabra impresa, primero en la forma de libros y después como diarios, proveía el 'menú' para las conversaciones, y el habla se fusionaba en juicios colectivos, los cuales regresaban a la imprenta como expresiones de los puntos de vista del público». ${ }^{30}$ En el caso francés, la aparición del diario barato y la alfabetización masiva en Francia que transformó la naturaleza de la lectura fueron algunos de los factores que influyeron en esta relación.

Earle, para el caso de Nueva Granada, también hace énfasis en la importancia del estudio conjunto de ambas vías: la escrita y la oral. Para esta autora son varios los factores que deben ser tomados en cuenta al estudiar la difusión de la información en el periodo previo a la Independencia: el nivel de alfabetización de la población, por supuesto; el número de imprentas y su distribución geográfica; el desarrollo de la prensa periódica; y, fuera del ámbito de la palabra escrita, el mundo de la conversación y el rumor. ${ }^{31}$ La conversación y el rumor, para ella, pesaban tanto como el resto de factores, pues en una sociedad mayoritariamente iletrada como la de Nueva Granada de aquella época, esta era la manera más efectiva para transmitir la información.

una de ellas brinda cierto tipo de información con características propias. Al respecto, véase Rosas 2006: 53-96.

${ }^{29}$ Darnton 2010b: 6.

${ }^{30} \mathrm{Ib} .: 15$.

${ }^{31}$ Earle 1997: 168-175. 
La situación en el virreinato peruano era parecida a aquella descrita por Earle para el caso vecino. Si bien Lima contaba con algunos talleres tipográficos a inicios de la década de 1810, otras ciudades importantes del Perú no contaron con uno sino hasta después de proclamada la Independencia. Por ello, las noticias sobre los acontecimientos políticos más importantes, en una sociedad en donde no solo no existía la prensa sino que además albergaba a una población predominantemente analfabeta, se esparcían sobre todo de manera oral. Y no siempre se mantenía un solo relato de lo sucedido, sino que, justamente por la naturaleza de las formas orales, era común que circularan versiones diversas y creativas de lo sucedido. Como señala Charles Walker, durante la crisis de la monarquía española, "los rumores sobre el destino del rey, sobre los cambios radicales en España y sobre la subversión en el sur» se esparcían por todo el Cusco y aumentaban el pánico de los realistas. ${ }^{32}$ El desarrollo de una industria tipográfica local no acabó con estas formas de comunicación, solo las complementó.

Así, pues, es importante comprender que, cuando se trata de la difusión de textos impresos, sus contenidos mutaban con facilidad a formatos orales, dado que no todos tenían acceso a la palabra escrita. Al igual que hoy en día, era común que algunas gacetas se exhibiesen para la venta en lugares públicos, en donde los lectores podían revisar y comentar los titulares incluso sin la necesidad de comprarlos. De este modo, los locales que exhibían o ponían a la venta las gacetas que se volvieron populares en esta época se convirtieron en importantes puntos de reunión en donde se producían este tipo de intercambios. ${ }^{33}$ Siempre había quienes "podían

\footnotetext{
32 Walker 2004: 120.

${ }^{33}$ Charles Walker registra, para Cusco, la exhibición de El Sol en el exterior del Colegio de Ciencias y Artes, en donde las personas, de pie frente a él, lo podían leer. También señala la venta de El Sol del Cuzco en la botica de don Mariano Torres, situada frente al Convento de La Merced, y de El Triunfo de la Libertad en el almacén de don Pedro Vargas, en donde la gente podía leer estos periódicos sin necesariamente comprarlos primero. Si bien estas escenas son descritas para los primeros ańos de la década de 1830 , son significativas porque muestran cómo se iban perfilando los espacios públicos (Walker 2004: 222).
} 
leer las noticias en voz alta, lo que generalmente originaba discusiones». ${ }^{34}$ En este sentido, era la mezcla entre las vías escritas y las vías orales la que lograba que las noticias circulasen eficientemente en esos años.

Es cierto, entonces, que el «menú» para las conversaciones que interesaban a los pobladores de determinadas ciudades lo proveía la gran cantidad de "papeles públicos» que circulaba por país, como lo sugirió Darnton. El tipo de conversaciones y rumores que se producían a partir de estos impresos es algo difícil de rastrear, pero su importancia no pasó desapercibida ni por el bando patriota ni por el realista. La imprenta permitía difundir de manera más extensa y exacta el conocimiento; en este caso, el resultado de los enfrentamientos bélicos que se producían en distintas partes del territorio y las decisiones que tomaban los mandos de cada bando. Dicha información era recibida y comentada en distintas esferas de la sociedad. De esta manera, un discurso que había sido pronunciado frente a un determinado grupo de personas podía ser luego leído y repetido en diferentes lugares del país y del continente gracias a la producción impresa y a las distintas formas de difusión existentes.

El carácter propagandístico de la imprenta en este periodo era innegable: las gacetas no solo difundían noticias y documentos de carácter oficial, sino también efusivas proclamas que instaban a la población a actuar a favor de uno u otro bando. Se puede observar que estos textos, a pesar de su forma impresa, parecían haberse escrito para difundirse oralmente. Su objetivo, después de todo, era llegar a la mayor cantidad de personas posible: no estaban dirigidas solamente a un público letrado. En los bandos y proclamas de San Martín, por ejemplo, se encuentran expresiones coloquiales y entusiastas que apuntan a convencer a un público bastante extenso:

Por tanto, ciudadanos, mi corazón que nada apetece más que vuestra gloria, y a la qual consagro mis afanes; he determinado que el sábado inmediato veintiocho se proclame vuestra Feliz Independencia y el primer paso que dáis a la Libertad de los Pueblos Soberanos. ${ }^{35}$

${ }^{34}$ Walker 2004: 222.

${ }^{35}$ Gaceta del Gobierno de Lima Independiente. Tomo 1, núm. 5, 25 de julio de 1821: 18. 
¡Peruanos! Habéis logrado sacudir el ominoso yugo de la servidumbre. Ahora os falta lo más esencial, que es, la conservación de los bienes que trae consigo la Independencia [...]. Limeńos: vosotros que sois tan decididos por la libertad e independencia del Perú, a vosotros corresponde dar el ejemplo de firmeza e ilustración que os es característico. ${ }^{36}$

Se observa que San Martín se dirige directamente a sus lectores y oyentes — aquellos que no leen los "papeles públicos» directamente pero que sí escuchan a otros leerlos_ llamándolos «ciudadanos», "peruanos» y «limeños» de una manera que podría reconocerse como cariñosa y hasta lisonjera. De forma contraria, en una proclama escrita al abandonar Lima, La Serna se dirige a los "pueblos del Perú» en un tono mucho más amenazador y paternalista:

Siendo esta la primera vez que os hablo directamente, debo recordaros mi conducta con vuestros hermanos del Alto-Perú, cuando tuve el honor y placer de mandar aquel ejército [...]. Indios, no seáis víctimas del engaño, y abrazad el saludable consejo que os anticipo: no despreciéis mis promesas que por experiencia sabéis que cumplo; pero temed, si las desprecias porque no en valde he movido todas mis fuerzas. ${ }^{37}$

En ambos casos, se puede notar cómo estos impresos buscaban reproducir el tipo de comunicación que se produce de manera oral. Este estilo era en parte herencia de la cultura retórica y la oratoria sacra. ${ }^{38}$ Pero además estaban pensados para ser leídos en voz alta: su objetivo era convencer y, para lograrlo, debían imitar las formas orales. Es así que la comunión entre lo escrito y lo oral no se da en un solo sentido, sino que la influencia de un canal sobre el otro es mutua, al punto de no ser posible concebir el circuito de la comunicación sin considerar el peso de la oralidad.

${ }^{36}$ Ib., núm. 13, 22 de agosto de 1821: 59.

${ }^{37}$ Ib., núm. 9, 8 de agosto de 1821: 37.

${ }^{38}$ Agradezco los comentarios de los evaluadores anónimos por esta observación. 


\section{LECTURA Y DISCUSIÓN DE PAPELES PÚBLICOS}

Como ya se mencionó, las principales ciudades del Perú en aquella época —Lima, Trujillo, Arequipa, Huamanga y Cuzco- desarrollaron una actividad tipográfica importante a partir de 1820. En Lima, incluso antes de la Emancipación, y con mayor libertad después de ella, circularon gacetas de Buenos Aires y Santiago de Chile con propaganda clandestina patriota que se pasaba de mano a mano y se repetía con discreción. Estas gacetas podían, a veces, ser conducidas por agentes especiales o por marinos de las naves mercantes que visitaban el litoral, depositadas en lugares convencionales de la extensa y desierta costa, trasladadas hasta Lima y, luego, distribuidas con cuidado. Otras veces, mediante papeles manuscritos que reproducían las noticias de los impresos, eran deslizadas sigilosamente en residencias aristocráticas o humildes moradas, o incluso a veces adheridas a los muros de edificios públicos. ${ }^{39}$

Además del interés oficial por producir y difundir ciertos mensajes a través de la palabra impresa, había un genuino interés por parte de la población por acceder a la literatura política de la época. El 14 de octubre de 1821, por ejemplo, Juan Ignacio Machado firma una carta dirigida a Tomás Diéguez, vicario de la doctrina de Catacaos, en la que le pide encargar a Lima dos «obritas» que se podían conseguir ahí. Se trataba de «El Clamor de la Justicia e Ydioma de la verdad», que acababa de ser reimpresa, y de «Manifestación Histórica y política de la revolución de la América», que había sido "escrita en el mismo Lima y remitida a Buenos-Ayres para su impresión que se hiso en el año de $1818 » .{ }^{40}$ Para el remitente, conseguir y leer estos escritos era de suma importancia "para que todo Americano se penetre de sus derechos y de la injusticia con que hemos sufrido una esclavitud tan larga». En la misma misiva recomienda también la lectura de Los Andes Libres, periódico patriota publicado en Lima que «es sin duda uno de los mejores escritos». ${ }^{41}$

39 Tauro 1971-1976, I: xx-xxi.

${ }^{40}$ Carta de Juan Ignacio Machado a Tomás Diéguez. Trujillo, 14 de octubre de 1821, Archivo General de la Nación, Colección Tomás Diéguez, 2.7.22, f. 1r.

${ }^{41} \mathrm{Ib}$. 
Antes del colapso del gobierno colonial y, sobre todo, antes de que se sancionara la libertad de imprenta, conseguir ejemplares de estas y otras obras con cierto contenido político podía resultar una tarea complicada, aunque no por ello se detuvo la circulación de este tipo de literatura. Las gacetas adquirieron un rol especialmente importante en este contexto. Por un lado, se encontraba la "prensa fidelista», cuyos ejemplos más notables lo constituían El Triunfo de la Nación y El Depositario. Y, por otro, se encontraba la "prensa patriota», conformada por títulos como El Pacificador del Perú —llamados a veces «pacificadores»—, Los Andes Libres —el periódico recomendado por Juan Ignacio Machado- y El Correo Mercantil, Político y Literario, entre tantos otros. ${ }^{42}$ Muchos de estos periódicos se podían leer sin problemas si sus contenidos se encontraban en la misma línea que la de la autoridad del momento. Pero, incluso cuando no lo eran y estaban abiertamente prohibidos por la Corona, había muestras de su lectura y de la forma en que se trasmitían sus contenidos a quienes no tenían acceso directo al material impreso.

La lectura de impresos relativos a la Independencia y la transmisión de sus contenidos se convirtió, de hecho, en un argumento muy común usado por los sacerdotes para asegurar, entre finales de 1821 y finales de 1822, su adhesión al nuevo sistema de gobierno republicano. De tal modo, por lo menos sesenta y nueve de los casi doscientos expedientes producidos por la Junta Eclesiástica de Purificación, la institución encargada de evaluar la lealtad a la causa patriota de los curas en el arzobispado de Lima, presentan testimonios que revelan la lectura de "papeles públicos». ${ }^{43}$ Entre ellos, además, son varios los que señalan que las noticias que llegaban hasta ellos se remitían efectivamente desde Santiago de Chile y Buenos Aires, los territorios ya liberados. ${ }^{44}$ Un ejemplo específico

\footnotetext{
42 Álvarez y Martínez Riaza 1992: 66-68.

${ }^{43}$ Se han consultado todos los expedientes reproducidos en Nieto Vélez (1971-1976) y los originales que se encuentran en el Archivo Arzobispal de Lima [en adelante AAL]. ${ }^{44}$ Véanse los casos de los sacerdotes Manuel Arescurenaga, Manuel Arnao, Manuel de Gárate, Pedro de la Hoz, Juan Antonio Iglesias, José Joaquín de Larriva y José María del Piélago, que hacen referencias generales a los «papeles públicos» que les llegaban del extranjero (Nieto Vélez 1971-1976, I: 76, 86, 250, 349, 365-366, 384-385, 389; II: 170).
} 
es el cuaderno titulado Catecismo Político Cristiano dispuesto para la instrucción de la juventud de los pueblos libres de la América Meridional, firmado por don José Amor de la Patria — sin duda, un seudónimo-, hecho en Buenos Aires y encontrado en manos del franciscano Vicente Fernández. Este caso es especial, porque el sacerdote no solo da cuenta de la lectura del cuaderno, sino que también señala que conservaba una copia manuscrita de este que él mismo elaboró. ${ }^{45}$ También se reporta el caso del presbítero Manuel Gárate, que no solo recibe y comenta los papeles públicos que llegan de fuera, sino que, además, es mencionado en un impreso chileno a cargo de Cayetano Requena. ${ }^{46}$

A los peticionarios de la Junta Eclesiástica de Purificación les interesaba presentar testigos que declararan haberlos visto leyendo estos y otros impresos con agrado, ya que de ello dependía su permanencia en los beneficios eclesiásticos. La lectura era considerada una actividad importante, además de amena y estimulante: el sacerdote Vicente Gago señala, por ejemplo, que «no había rato más placentero [...] que el estar leyendo los papeles de Pacificador y Boletines». ${ }^{47}$ Estos «papeles públicos», según el presbítero Francisco Javier Aguinagalde, «salen a luz para instruir, y glosar extensivamente sus contenidos a todos sus compatriotas». ${ }^{48}$ En ese sentido, casi siempre se señala una lectura conjunta, entre el sacerdote y el testigo que daba cuenta de ella. Además, era muy común la alusión a la confianza depositada entre los lectores y los oyentes, sobre todo cuando la lectura de estos papeles estaba todavía prohibida por el gobierno colonial.

Los principales lectores de toda esta literatura política, además de las autoridades y los sacerdotes —y los guerrilleros, como se verá más adelante-, eran los miembros de la élite letrada que apenas representaban un porcentaje muy pequeño de la sociedad. ${ }^{49}$ Sin embargo, era un segmento importante que logró encontrar espacios de lectura adecuados:

\footnotetext{
45 Nieto Vélez 1971-1976, I: 224.

${ }^{46}$ Ib.: 250-251.

${ }^{47}$ Ib.: 243 .

${ }^{48}$ Ib.: 47.

${ }^{49}$ Peralta 2010: 148.
} 
uno de ellos era el café. Al principio, a partir de la segunda mitad del siglo XVIII, estos actuaban solo como espacios de diversión y contacto social, pero pronto se estableció la moda consistente en acudir a estos ambientes públicos para sentarse a leer los periódicos. ${ }^{50}$ Además, mientras que las imprentas, librerías y puertos eran constantemente registrados por el gobierno y la Inquisición por ser sospechosos de propiciar lecturas censuradas, los cafés se libraron de estas medidas, a pesar de ser espacios que permitían la lectura y la conversación. Al comenzar el siglo XIX, eran ocho los cafés que funcionaban en Lima. Si bien dos de ellos, los ubicados en las calles de Mercaderes y de Bodegones, se convirtieron en lugares exclusivos para la aristocracia, a los otros seis solían asistir también los sectores medios de la población. ${ }^{51}$ Así, estos espacios, a la vez que continuaron siendo los predilectos por las clases medias y altas para el esparcimiento, permitieron que sus asistentes acudieran a ellos para «ocuparse de novedades y sostener conversaciones sobre las materias que llamaban la pública atención». ${ }^{52}$

La discusión de los contenidos de los papeles públicos de la época era, pues, tan o más importante que su lectura. Por ello, antes de la llegada de San Martín al Perú y la partida del ejército realista de la ciudad de Lima, abundaban las referencias a las «conversaciones privadas» que se sostenían a partir de la lectura de los impresos que se pasaban de mano en mano, ya sea en alguno de los cafés mencionados o en lugares más discretos. El diácono Mariano Taboada, por ejemplo, señala que él contribuía a la causa patriota «esparciendo noticias favorables que adquiría, repartiendo proclamas que lograba y procurando extender nuestra opinión por medio de sus conversaciones, dirigidas todas a probar la justicia de nuestra causa». ${ }^{53}$ De esta manera, la lectura de los textos relativos la Independencia iba casi siempre de la mano con la discusión de sus contenidos.

Realizar estas lecturas, ya sea de manera privada o conjunta, casi siempre implicaba la afinidad del testigo presentado por el sacerdote

${ }^{50}$ Peralta 2002: 29.

${ }^{51}$ Ib.: $39-40$.

52 Ib.: 40.

${ }^{53}$ Nieto Vélez 1971-1976, II: 293. 
con este en cuanto a materias de política. Se trataba, pues, de una forma en la que se transmitía la información. Los espacios de sociabilización en los que se sostenían las "conversaciones privadas» sin duda contribuían a la formación de la opinión pública, como lo sugirió Darnton. Pero si se quiere medir cuán extenso era el circuito por el que viajaba la información y las noticias en este periodo, deben también considerarse otros factores. Después de todo, los sacerdotes no solo tenían contacto con otros individuos en calidad de amigos, con los que podían discutir de uno a uno los últimos acontecimientos, sino que también se relacionaban con un considerable número de fieles sobre los cuales podían influir.

\section{LA IGLESIA Y LAS PROCLAMAS DEL CLERO}

La labor del clero, en ese sentido, era especialmente importante, no solo porque se trataba de un grupo mayoritariamente educado que podía leer la literatura que circulaba en el momento, sino por las propias características de su cargo, que los convertían en personajes perfectos para la persuasión. Se debe entender, para comenzar, que, al igual que el resto de la sociedad colonial, los miembros de la Iglesia tomaron diversas posiciones durante la guerra de Independencia americana. Así como existían curas patriotas que decían leer y compartir textos a favor de la Independencia, también había sacerdotes que rechazaban las ideas emancipadoras e incentivaban la fidelidad al rey. La Iglesia, aunque unida en teoría por los mismos principios, no era un cuerpo homogéneo, menos en momentos de cambios y crisis como este. En esta época, además, esta institución estaba estrechamente vinculada con el Estado. Las esferas de la religión y la política difícilmente se separaban, por lo que, como Roberto di Stefano señala, «más que llamar la atención la existencia de ese fenómeno llamado 'politización del clero', debería maravillar que hubiese ocurrido lo contrario, es decir, que el clero hubiese logrado mantenerse al margen de un proceso de semejantes alcances». ${ }^{54}$

La importancia del clero, en especial si abogaba por la causa patriota, se debía en buena medida a que en sus manos estaba el poder explicar,

${ }^{54}$ Di Stefano 2004: 93. 
de manera sencilla pero eficiente, «que la revolución no constituía una traición al rey, a la patria ni a la religión, sino todo lo contrario». ${ }^{55} \mathrm{Si}$ bien, desde un punto de vista jurídico y político, la Independencia se apoyaba en el derecho natural, articular un discurso coherente en el plano religioso que justificara y legitimara esta ruptura era igual de importante. ${ }^{56}$ Para ello, se podía hacer uso de la propia Biblia. Di Stefano, por ejemplo, para el caso de Argentina, ha documentado la forma en que ciertos sacerdotes obtenían de las Sagradas Escrituras — sobre todo de los episodios del Antiguo Testamento- las claves para avivar el espíritu revolucionario de los fieles y, de alguna forma, sacralizar la guerra. ${ }^{57} \mathrm{En}$ el Perú, se puede documentar el mismo fenómeno, pues las metáforas bíblicas también están presentes en las proclamas de algunos sacerdotes peruanos. No faltó un cura que se refirió al general San Martín en su condición de Protector en los siguientes términos:

Nuestros corazones deben ser penetrados de los más vivos y tiernos sentimientos, de gratitud y de reconocimiento al Señor Dios de los Exércitos, quien se ha servido de Nuestro Excelentísimo Señor Protector, como de un Poderoso Instrumento, para grangeárnosla: como en otro tiempo se valió del Gran Profeta Moisés, para Livertar a su Pueblo Elegido dela Esclavitud y Tiranía del Rey Faraón, y a pesar de ser tan claros los Designios dela Providencia a Nuestro favor, quieren Nuestros Opresores (imitando la obstinación y Ambición de Faraón) restaurar su Antiguo Dominio. ${ }^{58}$

La prédica revolucionaria, precisamente, no solo tenía que ser teórica y erudita - aunque en un primer momento sí fueron necesarios los debates académicos para poder justificar la Independencia—, también podía ser didáctica y emotiva, según el público al que se dirigiese. De hecho, por lo menos para el caso peruano, son más frecuentes las proclamas de este último tipo. Así, la «fuerza simbólica» propia de la religión, «capaz de

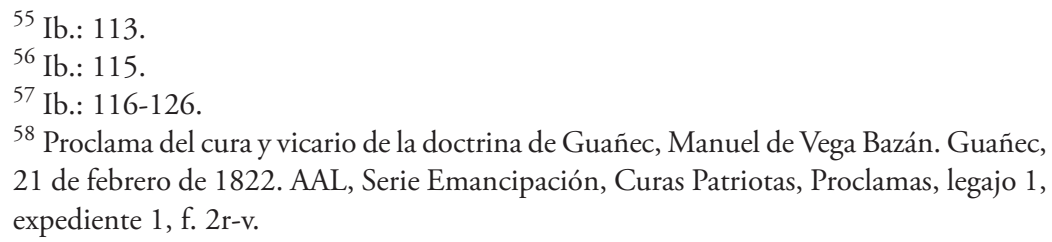


proporcionar sentido a la idea de morir en un campo de batalla», ${ }^{59}$ puede explicar relatos como el de Palma sobre el coronel y fraile Terreros con el que se inició este ensayo y sugerir que en este hay menos de ficción que de realidad.

Se conocía tan bien la importancia del rol del clero que, desde la capital, el gobierno de San Martín requirió a los sacerdotes de la diócesis limeña predicar proclamas en favor de la causa patriota y que las versiones escritas de sus sermones fueran remitidas al deán de la catedral, Francisco Xavier de Echagüe (a su vez, administrador de la diócesis) en un plazo de dos meses para su impresión. Esta medida lograba unir el poder de persuasión del clero con el poder de difusión de la imprenta, que seguía aumentando a medida que más talleres iban apareciendo a lo largo y ancho del territorio. Aunque no en todos los casos se han conservado las proclamas, fueron varios los que cumplieron con enviarle sus escritos a Echagüe. Las misivas que las presentaban, además, solían dar cuenta de la forma en que se afrontarían los costos de la impresión. Francisco de Pascual Eraso, por ejemplo, señala que su hermano iba a ser quien corriera con los gastos, en caso las autoridades decidieran publicar su texto. ${ }^{60}$ Lo mismo Juan Manuel Nocheto, quien tenía «a un hermano mío vecino de esa capital». ${ }^{61}$ Juan Dios Lobato, mientras tanto, le había delegado la responsabilidad a un apoderado. ${ }^{62}$ Manuel Castellanos, en cambio, pide que la impresión se hiciese a su costa, «teniendo la bondad de corregirla primero de los defectos que no he podido preveer a causa

${ }^{59}$ Di Stefano 2004: 115.

${ }^{60}$ Carta a Francisco Xavier de Echagüe del cura de Ica, Francisco de Pascual Eraso. Ica, 16 de marzo de 1822. Archivo Arzobispal de Lima, Serie Emancipación, Curas Patriotas, Proclamas, legajo 1, expediente 5, f. 1.

${ }^{61}$ Carta a Francisco Xavier de Echagüe del cura de Pachas, Juan Manuel Nocheto. Pachas, 21 de marzo de 1822. AAL, Serie Emancipación, Curas Patriotas, Proclamas, legajo 1, expediente 8 , f. 1 .

${ }^{62}$ Carta a Francisco Xavier de Echagüe del cura de San Juan Bautista de Ica, Juan Dios Lobato. San Juan Bautista de Ica, 20 de marzo de 1822. AAL, Serie Emancipación, Curas Patriotas, Proclamas, legajo 1, expediente 6, f. 1. 
de la precipitación con que se formó en cumplimiento de las superiores determinaciones». ${ }^{63}$

Es preciso indicar que estas proclamas debían contar con la autorización del deán antes de ser publicadas. Podían ser corregidas, como sugiere el testimonio anterior, y los autores eran conscientes de ello: "[remito la adjunta proclama] quedándome el sentimiento de no poseer toda la elocuencia que se requiere para llenar con dignidad el objeto; pero he puesto con voluntad lo que está a mi alcanze esperando que V. S. I. se digne corregir con su Ilustrado criterio aquello que no deba ver la luz pública». ${ }^{64}$ Solo en un caso un sacerdote se adelantó a la orden y no adjuntó su texto para que fuese evaluado primero sino que envió los ejemplares ya impresos: «le remito la Proclama impresa con otras dose más para que las haga circular en toda su Doctrina», ${ }^{65}$ dice la comunicación. Este último testimonio, además de demostrar una importante iniciativa, también da cuenta de la expansión de la industria tipográfica: ya no era necesario que un texto se enviase hasta Lima para que pudiera pasar por un taller.

\section{CIRCULACIÓN E INTERPRETACIÓN DE NOTICIAS}

Debe tenerse en cuenta que las comunicaciones no solo circulaban en las principales ciudades en las que se empezó a desarrollar una actividad tipográfica importante como consecuencia del conflicto, sino que estas constantemente pasaban del ámbito urbano al ámbito rural. El movimiento de las imprentas volantes en las campañas permitió y alentó este fenómeno, por supuesto. Pero para hacer que ciertos escritos llegaran

${ }^{63}$ Carta a Francisco Xavier de Echagüe del cura de Sayán, Manuel Castellanos. Sayán, 12 de marzo de 1822. AAL, Serie Emancipación, Curas Patriotas, Proclamas, legajo 1, expediente 4, f. $1 \mathrm{r}$-v.

${ }^{64}$ Carta a Francisco Xavier de Echagüe del cura de San Juan Bautista de Ica, Juan Dios Lobato. San Juan Bautista de Ica, 20 de marzo de 1822. AAL, Serie Emancipación, Curas Patriotas, Proclamas, legajo 1, expediente 6, f. 1.

${ }^{65}$ Recibo del oficio de Francisco Xavier de Echagüe suscrito por el cura de Ciscas, José Amancio Monge. Ciscas, 9 de marzo de 1822. AAL, Serie Emancipación, Curas Patriotas, Proclamas, legajo 1, expediente 2, f. 1. 
a los lugares más recónditos, también fue necesario valerse de traslados clandestinos o reproducciones manuscritas. ${ }^{66}$ Ese fue el caso del ya mencionado presbítero fray Vicente Fernández, quien conservaba una copia manuscrita de un texto bonaerense hecha por él mismo.

Los ejércitos patriotas y realistas que se internaron en el sur y norte del país precisaban enviar y recibir noticias constantemente, no solo para poder tomar decisiones de carácter bélico, sino también para satisfacer la necesidad de información sobre los seres queridos y la situación general en el resto del país. Las cartas, en ese sentido, eran sumamente valiosas, tanto las transmitidas entre los oficiales como las que se enviaban los familiares que se encontraban lejos. Por ejemplo, el 26 de febrero de 1822, la esposa del entonces coronel patriota Francisco de Paula Otero, Petronila Abeleyra, le escribió a su marido una misiva en la que, además de detallarle las prendas y víveres que le estaba enviando, menciona la forma en que las noticias llegaban hasta ella:

Mi cienpre apreciadícimo Pancho, todo estos días e estado con bastante sobre salto de no saber a dónde se dirigía las tropas que estaban reunidas en Tarma, yo estube persuadida que cin duda seria para pasar a Huánuco, pero ya de algún modo quedo tranquila porque ayer supe por uno que vino de Huaypacha que todos los que estaban en Tarma se han vuelto a Jauja quiera Dios que nunca se aquerden de volver a ese cerro, para que no tenga la pension de estar trotando. ${ }^{67}$

En esta misiva, la esposa del coronel afirma conocer la ubicación de las tropas enemigas gracias a las personas que iban de un lugar a otro y a lo que Earle ha llamado el rumor. ${ }^{68}$ Esta información, por supuesto, no siempre era confiable, pero podía ser la única que se tenía. Por ello, difundir noticias falsas, como se explica líneas abajo, podía ser tan valioso como difundir información real.

La necesidad de noticias hacía que muchos, en sus cartas, pidiesen expresamente el envío de los periódicos que circulaban en las capitales

\footnotetext{
${ }^{66}$ Nieto Vélez 1971-1976, I: 224.

${ }^{67}$ Temple 1971-1976, II: 82-83.

${ }^{68}$ Earle 1997: 167-184.
} 
y que difícilmente, por lo menos en un inicio, llegaban a poblados muy alejados. Un ejemplo es el caso del jefe patriota Juan Pardo de Zela, quien se dirigió a Bernardo de Monteagudo, ministro de Guerra y Marina, para pedirle que le «remita todos los papeles públicos que sean interesantes para remitirlos a los pueblos donde les han sembrado algunas noticias melancólicas que los han arredrado». ${ }^{69}$ Estos "papeles públicos» tenían el objetivo de entusiasmar a favor de la causa patriota a los partidos de Parinacochas, debido a su ubicación estratégica sobre Arequipa y Cuzco. Se sabe que su importancia no fue pasada por alto por las autoridades pues, varios días después, se puede encontrar una confirmación del recibo de «las colecciones de papeles públicos» solicitados y el pedido de seguir enviando más. ${ }^{70}$ También el militar patriota Marcelino Carreño se dirigió a Tomás Guido, el Ministro de Guerra y Marina del gobierno de San Martín, para pedirle que le envíe «algunos ejemplares de las Proclamas de su Excelencia el Protector y algunos ejemplares de la Gaseta $N^{\circ} 6$ del sábado 13 del corriente». ${ }^{71} \mathrm{~A}$ diferencia de la comunicación anterior, este último no da más detalles sobre su propósito.

Por supuesto, con este sistema, un riesgo muy presente era que el enemigo interceptara las cartas o circulares. Este riesgo se evidencia en la carta que le escribió Miguel Otero a San Martín en marzo de 1821, en la que omite determinada información "por no aventurar un compromiso funesto, en caso de ser interceptada esta [carta]». ${ }^{72}$ Después de todo, apoderarse de la correspondencia enemiga era una forma de obtener valiosa información sobre las acciones del bando contrario. Un ejemplo es Domingo Tristán, del ejército patriota, quien le escribió a Tomás Guido en febrero de 1822 para remitirle el bando y la correspondencia del militar español José Carratalá que sus espías habían logrado interceptar. ${ }^{73}$ Los impresos, por último, también podían usarse para crear falsas noticias y confundir al enemigo. Francisco de Paula Otero le escribió

\footnotetext{
${ }^{69}$ Temple 1971-1976, I: 406.

${ }^{70}$ Ib.: 444.

${ }^{71}$ Ib., II: 308.

72 Ib., I: 264.

${ }^{73}$ Ib., II: 79-80.
} 
a San Martín al respecto, contándole cómo había recibido varios partes con información sobre la proximidad del ejército realista y cómo duda de la veracidad de esa información: «lo que si me parece probable es que estén comunicando órdenes a los pueblos por tenerlos alucinados», es la conclusión a la que Otero llegó. ${ }^{74}$ Para Juan Pardo de Zela, citado líneas arriba, el malestar era doble, pues al intento de los enemigos realistas de «sembrar noticias funestas, de las quales hando indagando el origen para castigarlo como corresponde», se le unía el hecho de no recibir suficientes noticias de la capital de su propio bando. ${ }^{75}$

\section{LOS CURAS PATRIOTAS EN (LA) CAMPAÑA}

Como se ha podido ver, no solo los que habitaban las grandes ciudades podían tener acceso a la gran cantidad de impresos que circulaban en la época, sino que este contacto también se podía dar en las localidades más pequeñas del virreinato. El que buena parte de la población fuese iletrada tampoco era un impedimento, pues existían personas que leían y difundían las noticias relativas a la guerra y los mensajes propagandísticos publicados por uno u otro bando. El rol de los sacerdotes, en ese sentido, era aún más importante en el campo que en la ciudad: en sociedades mayoritariamente analfabetas, «en donde la circulación de la propaganda y de la información dependía más bien de los recursos orales que de los escritos, la voz del clero parroquial parecía la más adecuada para transformar eficazmente la palabra escrita en mensaje proclamado». ${ }^{76}$ De esta manera, además de repartir entre sus conocidos las proclamas y oficios que les llegaban a sus manos, sacerdotes como Manuel de Arancibia se enorgullecían también de insertar en sus prédicas los discursos a favor de la Independencia, para convencer a todos los asistentes de la misa a unirse a ella. ${ }^{77}$

${ }^{74}$ Ib., I: 395.

75 Ib.: 406.

${ }^{76}$ Di Stefano 2004: 109.

77 Nieto Vélez 1971-1976, I: 60-64. 
Las autoridades eran conscientes de esta situación, por lo que, desde un principio, se alzaron advertencias sobre el poder del clero. Así, por ejemplo, Manuel Antonio de Gomes, subdelegado de Carabaya, le escribió al jefe político de la provincia Tadeo Joaquín de Gárate para prevenirle sobre el rol perjudicial de los sacerdotes:

La causa de esta enfermedad desde el principio de la guerra ha recidido en el Clero, y con particularidad en sus Párrocos que a pesar de las reiteradas súplicas de V.S. para que del Púlpito exorten a sus Feligreses y a la fidelidad a su Rey y Señor, y a la explicación del Catecismo del memorable Señor San Alberto, Arzobispo de Charcas, jamás he oído que hayan hablado de él = Puedo asegurar a V.S. que de las diez partes de habitantes que V.S. tiene en su Provincia hoy la novena está seducida y decidida con desorden que acaso no se pueda evitar si los Partidos no se guarnecen de alguna Tropa, o al menos haya una bolante circulándola con solo el objeto de inponerlos, y persuadirlos en que el Gobierno está sobre sus operaciones. ${ }^{78}$

Para el subdelegado, ellos tenían una influencia demasiado grande sobre sus fieles, pues, así como poseían la capacidad de exhortarlos a seguir siendo leales a la Corona, también podían exhortarlos a sumarse a la causa de la Independencia, lo cual era un peligro. Es interesante, además, la mención del Catecismo Real del obispo José Antonio de San Alberto, pues se trataba de un texto que circulaba desde 1786 y que había sido reeditado varias veces. Este texto defendía los principios tradicionales de la Iglesia católica y buscaba convencer a sus lectores - y oyentes- de que las verdades de la monarquía permanecían inalterables incluso frente a los más recientes acontecimientos. ${ }^{79}$ Por ello, se entiende el malestar del subdelegado de Carabaya al notar que algunos sacerdotes no hacían caso a la indicación de leer y explicar dicho libro.

Los sacerdotes no solo hacían uso de textos como este para, durante su prédica, argumentar en contra de la Independencia, sino que también recurrían a distinta literatura propagandística para defenderla. Los expedientes de la Junta Eclesiástica de Purificación albergan varios testimonios que señalan la efectividad de estas acciones. Por ejemplo, un declarante

\footnotetext{
${ }^{78}$ Temple 1971-1976, I: 78.

${ }^{79}$ Conde Tudanca 2013: 172-174.
} 
menciona lo siguiente cuando se refiere al presbítero Francisco Solano Pezet:

Desde el sagrado púlpito y en exhortaciones pribadas no a sesado de inculcar en estos principios convenciéndonos por ello de la utilidad que nos resultaría de nuestra adheción y unión a nuestros libertadores, quien al resibo de bandos, órdenes e instrucciones de la Superioridad, se a tomado el trabajo de explicarlo punto por punto a fin de que nos penetráramos de la liberalidad y bien que contenían. ${ }^{80}$

En el púlpito y en las conversaciones privadas, sacerdotes como este se daban el trabajo de abogar por la Independencia y de explicar los impresos que llegaban a sus manos "punto por punto». Había también quienes adoptaban un rol todavía más activo en la difusión de estos papeles públicos. El presbítero José Jenaro Pérez, por ejemplo, no solo diseminaba las noticias favorables a la Independencia, sino que hacía copias de las proclamas que recibía para esparcirlas en lugares públicos, para que así su difusión sea mayor a la que podía haber alcanzado con el tiraje original. ${ }^{81}$ El verdadero valor que le atribuían a la palabra impresa, además, podía reflejarse en acciones como las del presbítero José Noriega, quien no se contentaba con leer los impresos patriotas, y seguramente también difundir sus contenidos, «sino que los copiaba de su puño y letra, logrando formar una colección completa de ellos». ${ }^{82}$

Por último, un caso más extremo, aunque también más ilustrativo, es el del presbítero Juan José Gabino de Porras, quien, además de esparcir las proclamas, había «vendido hasta la ropa de su uso para costear propios que llevasen las noticias que se disponían en esta Corte para que tirasen con acierto sus planes de defensa, por lo que se halla en el día experimentando muchas indigencias». ${ }^{83}$ Casos como este y los citados líneas arriba demuestran el rol activo que los sacerdotes desempeñaron durante la guerra de Independencia. Si bien muchos de los testimonios

${ }^{80}$ Nieto Vélez 1971-1976, II: 293.

${ }^{81}$ Ib.: 149 .

${ }^{82}$ Ib.: 84 .

${ }^{83}$ Ib.: 211. 
que se encuentran en los expedientes citados pueden haber sido exagerados para probar un sentimiento patriótico que tal vez en la realidad fue mucho más tibio, lo que todos ellos demuestran es que había un reconocimiento real del rol de los sacerdotes como mediadores entre la cultura de las élites letradas y la plebe. En el ámbito rural, en donde los recursos orales eran más usados y efectivos que los escritos, ellos se constituyeron «como el más adecuado canal de comunicación entre el gobierno revolucionario y los destinatarios populares a los que se intentaba —en varios sentidos— movilizar». ${ }^{84}$

\section{A MODO DE CONCLUSIÓN}

Las autoridades de ambos bandos parecían comprender bien la importancia de la palabra impresa. No en vano un contemporáneo había dicho, en más de una ocasión, que para alcanzar la victoria se debía luchar tanto con «la pluma» como con «las armas». ${ }^{85}$ Pero, aunque gracias al desarrollo de la industria tipográfica los impresos podían llegar cada vez a más personas, eran todavía pocas las que podían leerlos de primera mano. Por ello, como se ha sostenido a lo largo de este artículo, para estudiar el verdadero alcance del material impreso que tanto el bando realista como el patriota se esforzaban en publicar y difundir, es indispensable analizar tanto las formas en que los papeles impresos pasaban de una mano a otra como la manera en que la información contenida en ellos se difundía de forma oral entre la población.

Estudiar la cultura del impreso a través de un esquema teórico como el circuito de la comunicación permite establecer vínculos concretos y directos entre los procesos de producción, circulación y recepción del material impreso. Sobre la circulación específicamente, además de resaltar el rol de la oralidad, se ha podido identificar a algunos de los agentes más importantes. Mientras que Darnton señalaba que los viajeros y los vendedores eran quienes permitían la circulación de libros,

${ }^{84}$ Di Stefano 2004: 113.

${ }^{85}$ Hipólito Unanue fue quien, en dos trabajos de temáticas muy diferentes, quizás en más, expresó esta convicción. Al respecto, véanse Unanue (1806: lxxvi; 1815: 87; y 1914: 393. Este texto fue publicado después de la llegada de San Martín a la capital. 
durante la guerra de Independencia en el Perú, además de la población civil que militaba o simpatizaba con la causa realista o patriota, fueron las autoridades militares de cada bando las más interesadas en que la palabra impresa llegara a todo el territorio peruano. El carácter propagandístico de la imprenta en estos años es innegable y esperable. Lo que es más interesante es que junto a los militares se encontraban los sacerdotes como agentes esenciales para la difusión de esta propaganda. El clero se encontraba en una posición hasta cierto punto privilegiada en cuanto a la propagación de mensajes se refiere. No solo tenían una plataforma fija dispuesta a recibir sus mensajes, sino que además contaban con la autoridad espiritual que su cargo les otorgaba. De esta forma, la voz del clero fue fundamental para difundir la propaganda y la información que las autoridades con tanto esmero se preocupaban en producir.

\section{BIBLIOGRAFÍA}

Adams, Thomas R. y Nicolas Barker. 2001. «A New Model for the Study of the Book». En Barker, Nicolas (ed.). A Potencie of Life: Books in Society. Londres: British Library, 5-43.

Álvarez, Jesús Timoteo y Ascensión Martínez Riaza. 1992. Historia de la prensa hispanoamericana. Madrid: Mapfre.

Amezúa y Mayo, Agustín G. de. 1951. "Cómo se hacía un libro en nuestro Siglo de Oro». En Opúsculos histórico-literarios. Madrid: Consejo Superior de Investigaciones Científicas, vol. 1, 331-373.

Araujo Espinoza, Graciela. 1954. Adiciones a 'La imprenta en Lima': 1584-1824. Tesis para optar el grado de Bachiller en Humanidades, Pontificia Universidad Católica del Perú, Facultad de Letras.

Bonilla, Heraclio y Karen Spalding. 2015. «La independencia en el Perú: las palabras y los hechos». En Contreras, Carlos y Luis Miguel Glave (eds.). La independencia en el Perú: ¡concedida, conseguida, concebida? Lima: Instituto de Estudios Peruanos, 39-73.

Calvo, Hortensia. 2003. «The Politics of Print. The Historiography of the Book in Early Spanish America». Book History. Vol. 6: 277-305. https://doi.org/10.1353/ bh. 2004.0003

Chartier, Roger. 1995. «Los libros, ¿̨hacen revoluciones?». En Espacio público, critica $y$ desacralización en el siglo XVIII: Los orígenes culturales de la Revolución francesa. Barcelona: Gedisa, 81-106.

Chartier, Roger. 2000. Las revoluciones de la cultura escrita. Diálogo e intervenciones. Barcelona: Gedisa. 
Conde Tudanca, Rodrigo. 2013. «El Catecismo Real de José Antonio de San Alberto: una manera de mantener a la población americana fiel a la monarquía». Anales de la Universidad Metropolitana. Vol. XIII, núm. 2: 167-188.

Darnton, Robert. 1987. «Los lectores le responden a Rousseau: la creación de la sensibilidad romántica». En Darnton, Robert. La gran matanza de los gatos y otros episodios en la historia de la cultura francesa. Ciudad de México: Fondo de Cultura Económica, 216-267.

Darnton, Robert. 2003. El coloquio de los lectores. Ensayos sobre autores, manuscritos, editores y lectores. Ciudad de México: Fondo de Cultura Económica.

Darnton, Robert. 2007. “What is the history of books?' Revisited». Modern Intellectual History. Vol. 4, núm. 3: 495-508. https://doi.org/10.1017/ S1479244307001370

Darnton, Robert. 2008. Los best sellers prohibidos en Francia antes de la Revolución. Buenos Aires: Fondo de Cultura Económica.

Darnton, Robert. 2010a. «¿Qué es la historia del libro?». En Darnton, Robert. El beso de Lamourette: reflexiones sobre historia cultural. Buenos Aires: Fondo de Cultura Económica, 117-146.

Darnton, Robert. 2010b. Mademoiselle Bonafon y la vida privada de Luis XV: circuitos de comunicación en la Francia del siglo XVIII. Lima: Pontificia Universidad Católica del Perú.

Denegri Luna, Félix (ed.). 1971-1976. Colección Documental de la Independencia del Perú. Tomo XXVI: Memorias, diarios y crónicas. Lima: Comisión Nacional del Sesquicentenario de la Independencia del Perú, 4 vols.

Di Stefano, Roberto. 2004. El púlpito y la plaza: clero, sociedad y política de la monarquía católica a la república rosista. Buenos Aires: Siglo XXI.

Earle, Rebecca. 1997. "Information and Disinformation in Late Colonial New Granada». The Americas. Vol. 54, núm. 2: 167-184. https://doi. org/10.2307/1007740

Eisenstein, Elizabeth. 2010. La imprenta como agente de cambio. Ciudad de México: Fondo de Cultura Económica.

Espejo, Gerónimo. 1971-1976. «Apuntes históricos sobre la Expedición Libertadora del Perú en 1820 por el coronel Gerónimo Espejo (antiguo ayudante del Estado Mayor del Ejército de los Andes)». En Denegri Luna, Félix (ed.). Colección Documental de la Independencia del Perú. Tomo XXVI: Memorias, diarios y crónicas. Lima: Comisión Nacional del Sesquicentenario de la Independencia del Perú, vol. 2, 369-429.

García Jordán, Pilar. 1991. Iglesia y poder en el Perú contemporáneo, 1821-1919. Cusco: Centro de Estudios Regionales Andinos Bartolomé de Las Casas.

Guerra, François-Xavier. 1992. Modernidad e independencias: ensayos sobre las revoluciones hispánicas. Madrid: Mapfre. 
Guerra, François-Xavier. 2002. “Voces del pueblo'. Redes de comunicación y orígenes de la opinión en el mundo hispánico (1808-1814)». Revista de Indias. Vol. LXII, núm. 225: 357-384.

Guibovich Pérez, Pedro. 2003. Censura, libros e inquisición en el Perú colonial, 15701754. Sevilla: Consejo Superior de Investigaciones Científicas, Universidad de Sevilla y Diputación de Sevilla.

Guibovich Pérez, Pedro. 2012. «Letras de molde y revolución: la imprenta durante la guerra de la independencia». En Mc Evoy, Carmen; Novoa, Mauricio y Elías Palti (eds.). En el nudo del imperio: independencia y democracia en el Perú. Lima: Instituto de Estudios Peruanos e Instituto Francés de Estudios Andinos, 131-149.

Guibovich Pérez, Pedro. 2014. Lecturas prohibidas. La censura inquisitorial en el Perú tardío colonial. Lima: Pontificia Universidad Católica del Perú.

Guibovich Pérez, Pedro. 2019. Imprimir en Lima. Historia y documentos, 1584-1750. Madrid/Frankfurt: Iberoamericana/Vervuert.

Huerta Vera, María Claudia. 2017. La cultura del impreso en la guerra de independencia peruana, 1820-1824. Tesis para optar por el título de Licenciada en Historia, Pontificia Universidad Católica del Perú, Facultad de Letras y Ciencias Humanas. http://tesis.pucp.edu.pe/repositorio/handle/20.500.12404/8680

Huerta Vera, María Claudia. 2019. «La palabra impresa durante la guerra de independencia peruana». En Peralta Ruiz, Víctor y Dionisio De Haro (eds.). España en Perú (1796-1824). Ensayos sobre los últimos gobiernos virreinales. Madrid: Instituto de Investigaciones Históricas de la Universidad Michoacana de San Nicolás de Hidalgo y Marcial Pons, 111-136. https://doi.org/10.2307/j.ctv10sm8nv.7

Laffitte, Julio M. 1950. «Prólogo». En Gaceta del Gobierno de Lima Independiente (edición facsimilar). Buenos Aires: Ministerio de Educación y Universidad Nacional de La Plata, XV-XCII.

Love, Harold. 2003. «Early Modern Print Culture Assessing the Models». Parergon. Vol. 20, núm. 1: 45-64. https://doi.org/10.1353/pgn.2003.0071

Martínez Riaza, Ascensión. 1982. «Los orígenes del periodismo doctrinario en Perú. El caso conflictivo de 'El Peruano'». Revista Quinto Centenario. Vol. 3: 109-134.

Martínez Riaza, Ascensión. 1984. «Libertad de imprenta y periodismo político en el Perú, 1811-1824». Revista de la Universidad Católica. Vols. 15-16: 149-177.

Martínez Riaza, Ascensión. 1985. La prensa doctrinal en la independencia del Perú, 1811-1824, Madrid: Eds. de la Cultura Hispánica e Instituto de Cooperación Iberoamericana.

Mc Evoy, Carmen. 1996. «El motín de las palabras: la caída de Bernardo Monteagudo y la forja de la cultura política limeña (1821-1822)». Boletín del Instituto Riva-Agüero. Vol. 23: 89-139.

Medina, José Toribio. 1904. La imprenta en Arequipa, el Cuzco, Trujillo y otros pueblos del Perú durante las campañas de la independencia (1820-1825): notas bibliográficas. Santiago de Chile: Imprenta Elzeviriana. 
Medina, José Toribio. 1966. La imprenta en Lima, 1584-1824. Santiago de Chile: Fondo Histórico y Bibliográfico José Toribio Medina, 4 vols.

Niada, Roberto. 2011. Al servicio del poder: La actividad editorial y tipográfica de Guillermo y Manuel del Río. Tesis para optar por el título de Licenciado en Historia, Pontificia Universidad Católica del Perú, Facultad de Letras y Ciencias Humanas.

Nieto Vélez, Armando (ed.). 1971-1976. Colección Documental de la Independencia del Perú. Tomo XX: La Iglesia. La acción del clero. Lima: Comisión Nacional del Sesquicentenario de la Independencia del Perú, 2 vols.

Oviedo, Juan de. 1861-1870. Colección de leyes, decretos y órdenes publicadas en el Perú desde el año de 1821 hasta el 31 de diciembre de 1859. Lima: F. Bailly, 16 vols.

Palma, Ricardo. 1983. Tradiciones Peruanas. Lima: Enrique Cappelletti Representaciones Editoriales, 6 vols.

Peralta Ruiz, Víctor. 2002. «Hábitos de lectura y pedagogía política». En En defensa de la autoridad. Politica y cultura bajo el gobierno del virrey Abascal. Perú, 18061816. Madrid: Consejo Superior de Investigaciones Científicas, 25-67.

Peralta Ruiz, Víctor. 2010. La independencia y la cultura política peruana (18081821). Lima: Instituto de Estudios Peruanos y Fundación M. J. Bustamante de la Fuente.

Peralta Ruiz, Víctor. 2011. «La pluma contra las Cortes y el Trono. La prensa y el desmontaje del liberalismo hispánico en el Perú, 1821-1824». Revista de Indias. Vol. LXXI, núm. 253: 729-758. https://doi.org/10.3989/revindias.2011.024

Peralta Ruiz, Víctor. 2015. «La revolución socavada. La cultura política del liberalismo hispánico en el Perú, 1808-1824». En Contreras, Carlos y Luis Miguel Glave (eds.). La independencia en el Perú: ¿concedida, conseguida, concebida? Lima: Instituto de Estudios Peruanos, 375-398.

Pezuela, Joaquín de la. 1947. Memoria de gobierno. Edición y prólogo de Vicente Rodríguez Casado y Guillermo Lohmann Villena. Sevilla: Escuela de Estudios Hispano-Americanos de la Universidad de Sevilla.

Ragas, José. 2009. «Prensa, política y cultura impresa en el Perú, 1810-1870». En Velázquez Castro, Marcel (comp.). La República de papel: política e imaginación social en la prensa peruana del siglo XIX. Lima: Universidad de Ciencias y Humanidades, 43-66.

Romero, Carlos. 2009. Adiciones a 'La imprenta en Lima' de José Toribio Medina. Lima: Pontificia Universidad Católica del Perú, Academia Nacional de la Historia y Fondo Universidad de San Martín de Porres.

Rosas, Claudia. 2006. Del trono a la guillotina: el impacto de la Revolución Francesa en el Perú (1789-1808). Lima: Instituto Francés de Estudios Andinos, Pontificia Universidad Católica del Perú y Embajada de Francia en el Perú. https://doi. org/10.4000/books.ifea.592

Rose, Jonathan. 2002. The Intellectual life of the British Working Classes. York: York University Press. 
Tauro, Alberto (ed.). 1971-1976. Colección Documental de la Independencia del Perú. Tomo XXIII: Periódicos. Lima: Comisión Nacional del Sesquicentenario de la Independencia del Perú, 3 vols.

Temple, Ella Dunbar (ed.). 1971-1976. Colección Documental de la Independencia del Perú. Tomo V: Guerrillas y montoneras. La acción patriótica del pueblo en la Emancipación. Lima: Comisión Nacional del Sesquicentenario de la Independencia del Perú, 6 vols.

Torre Revello, José. 1940. El libro, la imprenta y el periodismo en América durante la dominación española. Buenos Aires: Casa Jacobo Peuser.

Unanue, Hipólito. 1806. Observaciones sobre el clima de Lima, y sus influencias en los seres organizados, en especial el hombre. Lima: Imprenta Real de los Huérfanos.

Unanue, Hipólito. 1815. Observaciones sobre el clima de Lima, y sus influencias en los seres organizados, en especial el hombre. Segunda edición. Madrid: Imprenta de Sancha.

Unanue, Hipólito. 1914. «Los males de la guerra civil y el deber de los escritores». En Obras cientificas y literarias. Barcelona: La Academia, vol. 2, 392-393.

Vargas Ugarte, Rubén. 1953. «La imprenta en el Perú». En Impresos Peruanos (15841650). Lima: San Marcos, IX-LIV.

Vargas Ugarte, Rubén. 1957a. Impresos peruanos (1800-1817). Lima: Tipografía Peruana.

Vargas Ugarte, Rubén. 1957b. Impresos peruanos (1809-1825). Lima: Tipografía Peruana.

Vargas Ugarte, Rubén. 1971. Documentos inéditos sobre la campaña de la independencia del Perú. Lima: Milla Batres.

Walker, Charles F. 2004. De Túpac Amaru a Gamarra. Cusco y la formación del Perú Republicano (1780-1840). Segunda edición. Cusco: Centro de Estudios Regionales Andinos Bartolomé de Las Casas.

Fecha de recepción: 1/IX/2020

Fecha de aceptación: 29/X/2020 